\title{
The Relationship between Stress, Personality, Dopamine Transporter, and Serotonin Transporter Level with Internet Addiction in Secondary School Students in Padang
}

\author{
Yaslinda Yaunin ${ }^{1 *}$, Adnil Edwin Nurdin ${ }^{1}$, Eryati Darwin ${ }^{2}$, Yanwirasti Yanwirasti ${ }^{2}$ \\ ${ }^{1}$ Department of Psychiatry, Medical Faculty of Andalas University, Padang, West Sumatera, Indonesia; ${ }^{2}$ Biomedical, Laboratory, \\ Medical Faculty of Andalas University, Padang, West Sumatera, Indonesia
}

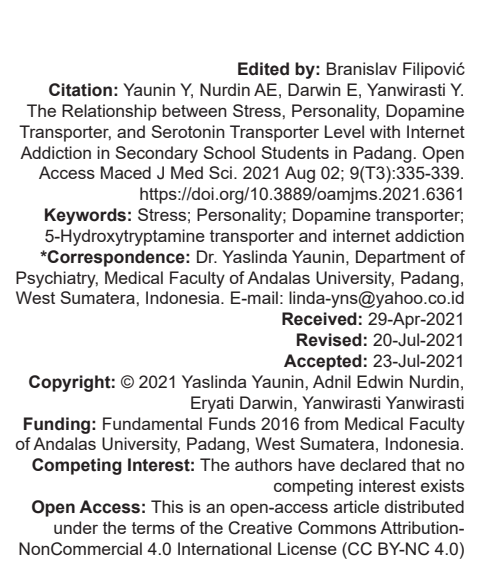

\section{Introduction}

The emotional response can be a fear that triggers a light or an angry response initiating a fight response [1]. This unpleasant stress can cause a variety of mental emotional disorder. Stress that cannot be controlled will negatively affect the lives of individuals. Academic self-efficacy will encourage students to take action in the face of challenges.

Wisantyo's research on Public Senior High School 3 Semarang students found that there was very significant relationship between academic self-efficacy and stress [2]. Study of 100 Malaysian government high school students in Kota Bharu (Kelantan) found the prevalence of stress was 26.1\% and this figure was relatively higher compared to a population with stress of $<10 \%$ [3]. The study of Jusuf et al. (2012) investigated the incident of stress in high school students in Gorontalo city; they found that stress level of $62.3 \%$ of students is not immune to stress; student of class I and III most experience wild stress [4]. Stress disorder will lead children to run away from real life and search for another life that could please them. One from of escapism is excessive internet use.

The development of internet has been very rapid and used to play games, make friendship, looking for jobs, shopping, etc. [5]. However, internet usage also has negative impact on people's lives. Internet addiction is defined as an inability to control internet usage, which causes obstacles in psychological and social functions [6], [7]. While Young refers to some of the symptoms of internet addiction that resembles the symptoms of substance addiction, namely, the feeling withdrawal, tolerance, and pre-occupation with the internet resulting in excessive internet use, causing physical and psychological problems [5], [8]. 
Baer studied 102 adolescents as outpatients in a psychiatric clinic at a Canadian Hospital found that approximately $94 \%$ of teens spent more than $2 \mathrm{~h} /$ day in front of a screen. Two hours/day is a recommended time by the American Academy of Pediatrics (AAP, 2001). It is suspected that adolescent with a psychiatric disorder will spend more time on computers/online games than the general population. Dependence on the internet in this study also aimed to investigate emotional and functional obstacles related to this problematic use of internet [9].

Kuss et al., (2013) determined that $4 \%$ of high school students in the United States were classified as internet addict [13].

Certain personality traits or personality disorders also affect someone using the internet. Shaw and Black found that $52 \%$ in their study met criteria for borderline personality disorder was found in $24 \%$, narcissistic $19 \%$, and antisocial 19\%, while others impaired avoiding, passive aggressive, and obsessive compulsion [11].

Other researchers pointed out that besides the impact on academic performance, internet addiction also affected physical health (sleep disturbance, grave time, dry eyes, and metacarpal syndromes) and mental fitness. Communication through the internet is considered important for teens who lack the ability to socialize as friends in the real world. Ayas and Horzum conducted a cross-sectional study on 292 students (2009-2010) in Trabzon (Turkey). The result showed an association between internet addiction and depression, loneliness, and self-esteem [12].

Several studies have tried to show a relationship between dopamine and internet addiction by measuring the level of dopamine transporter (DAT). Liu and Lou (2015) conducted a study of 33 teenagers with internet addiction and 33 healthy teens as controls. It turned out that dopamine levels in peripheral blood in teenagers who were addicted to the internet had significant differences [13]. Hou et al. (2012) stated that the expression of DAT levels in the striatum area decreased significantly and they suspected that internet addiction disorder was associated with a dysfunction of the dopaminergic system in the brain [14]. Previously, researchers have shown that changes in DAT concentration in the striatum occur in chronic substance addicts. In recent years, DAT has been used as an important clinical guide to determining brain structure changes in patients with substancerelated addiction [14], [15].

Serotonin (5-hydroxytryptamine [5HT]) system changes have also been investigated in relation of aggressive behavior and internet addiction. Lee et al. (2008) showed that one homozygous short allele from the serotonin transporter (SERt) gene $5 \mathrm{HT}$ transporter (5HTT)-linked polymorphic region is more frequent in excessive internet users. They also revealed that there was a serotonin system dysfunction in internet addiction disorders, as well as research into other addictive behavioral disorders. It is, therefore, reasonable to hypothesize that internet addiction is also associated with neurobiological aspects of serotonin system dysfunctions as well as in substance addictive disorders [16].

The aim of this study was to investigate the relationship between stress, personality, DAT, and SERt level with internet addiction in secondary school students in Padang, West Sumatera, Indonesia.

\section{Methods}

Before the study was conducted, an ethical clearance was approved by the Ethics Commission Research of Medical Faculty, Andalas University in Padang, West Sumatera, Indonesia. This study was a cross-sectional comparative study which was conducted between January 2016 until March 2017 in Padang, West Sumatera, Indonesia. The study population were secondary senior high school student whose had internet access and meet stress criteria according to the depression anxiety stress scale (DASS).

Our inclusion criteria were as follows: (1) The $2^{\text {nd }}$ year student in senior high school in Padang and meet stress criteria and (2) willing to participate in this study. Exclusion criteria were as follows: (1) Having a fever or disease that requires treatment; (2) female students were currently menstruating; (3) already having severe emotional distress before (such as depression or learning disorder that needs of treatment by doctors and/or psychologists); and (4) being or just experiencing severe life trauma such as death of person that loved and losing valuable items.

Young internet addiction questionnaire was given to determine student who was internet addicted and non-internet addicted. Peripheral blood sample was taken and then using the enzyme-linked immunosorbent assay (ELISA) system in Biomedical Laboratory of Medical Faculty, Andalas University in Padang to measure the level of DAT and SERt or 5 HTT.

\section{Results}

Data collection in the field was conducted on the $2^{\text {nd }}$ year students from 11 senior high school in Padang starting in February 2016 until June 2016. At the start of the study, we used the questionnaire from the DASS. A total of 681 students participated at the start of the study and it was found that $42.88 \%$ of the students $(n=292)$ 
experienced stress, whereas $57.12 \%(n=398)$ did not. After applying the inclusion and exclusion criteria, we got 147 students as sample for further investigation. The internet addiction questionnaire from Young was administered to determine the number of stressed students with addiction to the internet. The results revealed that 79 students (35 males and 44 females) with stress were also addicted to the internet, whereas 68 students (32 males and 36 females) with stress showed no internet addiction.

Table 1: The difference of personality between stress students and internet addiction with stress students not internet addiction

\begin{tabular}{lllllll}
\hline Personality & \multicolumn{2}{c}{ Stress and internet addiction } & & \multicolumn{2}{c}{ Stress not internet addiction } & p-value \\
\cline { 2 - 3 } & $\mathrm{f}$ & $\%$ & $\mathrm{f}$ & 57 & $\%$ & \\
\hline Adaptive & 62 & 78.48 & 21.52 & 11 & 83.82 & 0.271 \\
Maladaptive & 17 & 100 & 68 & 16.18 & \\
Total & 79 & & & & &
\end{tabular}

The 79 stressed students and internet addiction and 68 students stress not internet addiction give the Minnesota Personality Inventory to Adolescent (MMPI-A) questionnaire for determined personality trait and the result is shown in Table 1 . Maladaptive personality in stress students and internet addiction was found 17 students $(21.52 \%)$ while stress students were not addicted to internet only 11 students (16.18\%) (Table 2$)$.

Table 2: The difference of DAT levels between stress and internet addiction students and stress not internet addiction students

\begin{tabular}{lllll}
\hline Parameters & $\mathrm{n}$ & DAT level & p-value \\
\cline { 3 - 4 } & & Mean & Standard deviation & \\
\hline Stress and internet addiction & 79 & $13.28 \mathrm{nmol} / \mathrm{L}$ & $11.01 \mathrm{nmol} / \mathrm{L}$ & 0.001 \\
Stress not internet addiction & 68 & $9.83 \mathrm{nmol} / \mathrm{L}$ & $6.29 \mathrm{nmol} / \mathrm{L}$ & \\
\hline DAT: Dopamine transporter. & & & &
\end{tabular}

The average DAT in stress and addicted students was obtained $13.28 \pm 11.01 \mathrm{nmol} / \mathrm{L}$ compared to stress not addicted students with average DAT. $9.83 \pm 6.29 \mathrm{nmol} / \mathrm{L}$ statistical analysis found that $P=0.001(P<0.05)$ means that in this study, there were significant differences in the level of DAT in peripheral blood between students stress and internet addiction and stress students not internet addiction (Table 3).

Table 3: The difference of 5 HTT level between stress and internet addiction students and stress not internet addiction students

\begin{tabular}{lllll}
\hline Parameters & $\mathrm{n}$ & \multicolumn{2}{l}{5 HTT level } & p-value \\
\cline { 2 - 4 } & & Mean & Standard deviation & \\
\hline Stress and internet addiction & 79 & $18.37 \mathrm{nmol} / \mathrm{L}$ & $19.61 \mathrm{nmol} / \mathrm{L}$ & 0.001 \\
Stress not internet addiction & 68 & $12.96 \mathrm{nmol} / \mathrm{L}$ & $12.08 \mathrm{nmol} / \mathrm{L}$ & \\
\hline 5HTT: 5-hydroxytryptamine transporter. & & &
\end{tabular}

SERt levels was examined in Biomedical Laboratory of Faculty of Medicine Andalas University with the ELISA system.

It is not found that the average value of SERt in stressed and internet addicted students was higher: $18.37 \pm 19.61 \mathrm{nmol} / \mathrm{L}$, compared to stressed not addicted to internet with an average SERt $12.96 \pm 12.08 \mathrm{nmol} / \mathrm{L}$ with analysis statistic obtained $P=0.001(P<0.05)$ means that in this study, there were significant differences in SERt levels (5 HTT) in peripheral blood between students stress internet addiction with stressful students not internet addiction.
To determine the most related factors that influenced students become addicted to internet among personality, DAT or SERt analysis by logistic regression is shown in Table 4 . It is found that in the logistic regression analysis, it was obtained that $5 \mathrm{HTT}$ value was higher 0.534 ; personality value 0.499 and the lowest DAT value was 0.053 so that is means DAT levels play the most role in a student who was stressed being addicted to the internet.

Table 4: The logistic regression analysis

\begin{tabular}{lllllll}
\hline Parameters & B & SE & Wald & df & Sig. & Exp(B) \\
\hline Step 1(a) & -0.049 & 0.037 & 1.815 & 1 & 0.178 & 0.952 \\
$\quad$ DAT & -0.010 & 0.017 & 0.387 & 1 & 0.534 & 0.990 \\
5 HTT & 0.308 & 0.437 & 0.497 & 1 & 0.481 & 1.361 \\
$\quad$ Personality(1) & 0.296 & 0.533 & 0.307 & 1 & 0.579 & 1.344 \\
$\quad$ Constant & & & & & & \\
Step 2(a) & -0.060 & 0.032 & 3.656 & 1 & 0.056 & 0.941 \\
$\quad$ DAT & 0.295 & 0.436 & 0.456 & 1 & 0.499 & 1.343 \\
$\quad$ Personality(1) & 0.276 & 0.527 & 0.274 & 1 & 0.601 & 1.318 \\
$\quad$ Constant & & & & & & \\
Step 3(a) & -0.062 & 0.032 & 3.751 & 1 & 0.053 & 0.940 \\
$\quad$ DAT & 0.533 & 0.370 & 2.072 & 1 & 0.150 & 1.704 \\
$\quad$ Constant & \multicolumn{7}{l}{}
\end{tabular}

\section{Discussion}

The number of students participating at the start of the study was 681 students, 292 (42.88\%) students experiencing stress and 389 (57.12\%) students not experiencing stress. This figure was more than double of the estimate provided by the WHO of stress in adolescents in the world with around $20 \%$ and also higher than Yusoff's (2010) study found for stress prevalence $26.1 \%$ [3]; but it was lower than Jusuf et al. results (2012) in Gorontalo city which was 62.3\% [4].

Determining the personality of students using MMPI-A in stressed students with internet addiction found maladaptive personality in 17 students. This is a difference to the research of Shaw and Black (2008) which found $52 \%$ in their study met the criteria for personality disorder [11]. In this study, there are differences in numbers between maladaptive personality stress students and internet addiction and stress student not internet addicted but statistically, there is no significant difference. This is most likely due to the fact that the population and sample in this study are students in public and private high schools who still have good communication and relationship families, a good educational environment and not had severe psychosocial stressor.

The DAT levels in stressed students and internet addiction were $13.28 \pm 11.01 \mathrm{nmol} / \mathrm{L}$ and were higher than stressed students without internet addiction (9.83 \pm 6.29 $\mathrm{nmol} / \mathrm{L}$ with $P=0.001)$. Dopamine as a neurotransmitter which plays a role in regulating moods, emotions and motivation, and reward processed. Dopamine functions related to positive and negative reward depending on the component that has an abnormality [15]. Dopamine 
also can be mentioned as a pleasure center. Hou et al. (2012) stated that expression of DAT levels in striatum area decreased significantly and it was thought that internet addiction was associated with dopaminergic dysfunction in the brain [14]. The last few years DAT has been used as on the clinical guideline in determining brain structured changes in substance addicted patients [15]. Liu and Lou also found that dopamine levels in peripheral blood of adolescents who were addicted to the internet differed significantly compared to healthy adolescent as controls [13]. The results of this study indicate a recurring tendency to use internet until there is satisfaction and pleasure in stress and internet addicted group of students.

In this study, the mean level of SERt ( 5 HTT) in stressed students with internet addiction (18.37 \pm 19.61 $\mathrm{nmol} / \mathrm{L})$ was higher than in stressed students not internet addicted $(12.96 \pm 12.08 \mathrm{nmol} / \mathrm{L}, P=0.001)$. Serotonin functions as an inhibitory control or inhibition of excessive aggressive impulses. This study alone with Lee et al. (2008) showed that SERt level was higher in excessive internet user. They also showed the existence of a system dysfunction in internet addiction disorders, as well as other addictive behavior studies. Therefore, it is reasonable to say that it is related to serotonin system dysfunction as an aspect of neurobiological [16].

From the third variable in our study, personality, we were not able to show a significant difference for DAT and 5 HTT. There were significant differences between stress student and internet addiction and stress student not internet addict. After multivariate analysis using logistic regression, the highest level of 5 HTT was obtained: 0.534 , personality: 0.499 and the lowest DAT value: 0.053 . This implies that DAT levels may play the most important role in a student who is stressed becoming addicted to the internet.

\section{Conclusion}

Significant differences were found in peripheral blood DAT levels in students who were stressed and internet addicted compared with students who were stressed not internet addicted and also SERt (5 HTT) levels higher in students who were stressed and internet addicted. There is no difference in internet addicted based on personality. The most related factor in students who were stressed and internet addicted is level of DAT.

Further research is needed to look at the causes of a student become stressed and stress differences experienced by students based on "intelligence level" and the use of counseling teachers in schools for students who face problems.

\section{Declarations}

\section{Authors' contributions}

YY (author): Design the study, collecting and analyzed data, and make the manuscript. AEN (coauthor): Contribute the theory of psychiatry, the design study, and correcting the results of this study and the manuscript. ED and YW (coauthor): Contribute design study, data analyzed, draft writing, and review draft. All of the authors have read and approved the manuscript.

\section{Acknowledgments}

The authors thank to Dean of Medical Faculty of Andalas University, Padang, West Sumatera, Indonesia.

\section{Ethics approval and consent to participate}

Ethical clearance was approved by the Ethics Commission Research of Medical Faculty, Andalas University in Padang, West Sumatera, Indonesia. The parents of students with age $\leq 16$ years read, signed the informed consent, and agreed for their children to participate in this study.

\section{Availability of data and materials}

Wish to share by contact the email correspondence: linda_yns@yahoo.co.id

\section{References}

1. Sadock BJ, Sadock VA. Kaplan and Sadock's Synopsis of Psychiatry: Behavioral Sciences/Clinical Psychiatry. $11^{\text {th }}$ ed. Philadhelpia, PA: Wolfers Kluwer; 2015. https://doi. org/10.1097/00004850-198907000-00008

2. Wisantyo NI. Stres Pada Siswa SMAN 3 Semarang Ditinjau Dari Efikasi Diri Akademik Dan Jenis Kelas; 2010. Available from: http://www.eprintsundip.ac.id/10959/i/ringkasan.pdf. [Last accessed on 2021 Jan 14].

3. Yusoff MS. Stress, stressor and coping strategies among secondary school students in Malaysian government secondary School. ASEAN J Psychiatry. 2010;11(2):1-15.

4. Jusuf MI, Paramata N, Abud R. Epidemiological study of stress, stress tolerance and psychosocial stressors in high school students in the city of Gorontalo. Beranda. 2012;5(2).

5. Lu DW, Wong JW, Huang AC. Differentiation of internet addiction risk level based on autonomic nervous responses: 
The internet-addiction hypothesis of autonomic activity. Cyberpsychol Behav Soc Netw. 2010;13(4):371-8. https://doi. org/10.1089/cyber.2009.0254

PMid:20712495

6. Grohot JM. Internet Addiction Guide; 2013. Available from: http://www.psychcentral.com/netaddiction. [Last accessed on 2013 Jul 17].

7. Lee HW, Choi JS, Shin YC, Lee JY, Jung HY, Kwon JS. Impulsivity in internet addiction: A comparison with pathological gambling. Cyberpsychol Behav Soc Netw. 2012;15(7):373-7. PMid:22663306

8. Young K. Assessment of Internet Addiction, the Centre for Internet Addiction Recovery; 2014. Available from: http://www. google.com/ffg=assessment+of+internet+addiction. [Last accessed on 2014 Jan 22].

9. Baer S, Bogusz E, Green DA. Stuck on screens: Patterns of computer and gaming station use in youth seen in a psychiatric clinic. J Can Acad Child Adolesc Psychiatry. 2011;20(2):86-94. PMid:21541096

10. Kuss DJ, van Rooij AJ, Shorter GW, Griffiths MD, van de Mheen G. Internet addiction in adolescents: Prevalence and risk factors. Comput Hum Behav. 2013;29(5):1987-96. https://doi. org/10.1016/j.chb.2013.04.002

11. Shaw M, Black DW. Internet addiction: Definition, assessment, epidemiology and clinical management. CNS Drugs. 2008;22(5):353-65. https://doi. org/10.2165/00023210-200822050-00001

12. Ayas $T$, Horzum MB. Relation between depression, loneliness, self-esteem and internet addiction. Education. 2013;133(3):28390. Available from: http://www.questia.com/library/journal/igi357760558. [Last accessed on 2014 Apr 29].

13. Liu M, Luo J. Relationship between peripheral blood dopamine level and internet addiction disorder in adolescents: A pilot study. Int J Clin Exp Med. 2015;8(6):9943-8.

PMid:26309680

14. Hou H, Jia S, Hu S, Fan R, Sun W, Sun T, et al. Reduced striatal dopamine transporters in people with internet addiction disorder. J Biomed Biotechnol. 2012;2012:854524. https://doi. org/10.1155/2012/854524

PMid:22505818

15. Jovic J, Dindic N. Influence of Dopaminergic System on Internet Addiction; 2011. Available from: http://www.publisher. medfak.in.ac.rs//2011-html/i.broj/jelena\%20. [Last accessed on 2015 Nov 10].

16. Hahn C, Kim DJ. Is there a shared neurobiology between aggression and internet addiction disorder? J Behav Addict. 2014;3(1):12-20.

PMid:25215210

\section{Author Queries???}

AQ1: Kindly provide running title

AQ2: Kindly provide author initial

AQ3: Kindly provide department

AQ4: Kindly provide history details

AQ5: Please confirm the abstract subheadings

AQ6: Kindly check the author name does not match with reference list

AQ7: Kindly review the sentence as it seems to be incomplete.

AQ8: Kindly provide last accessed details

AQ9: Kindly provide page number

AQ10: Kindly provide in English language 